korespondencja z Leonem Choirosfaktesem, Romanem Lekapenem i wspomnianym Mikołajem Mistykiem. Z jednej strony widziano go, jako władcę wręcz idealnego, którego chętnie widziano by na bizantyńskim tronie, z drugiej zaś strony przypisywano mu tyranię. Nie brakowało Symeonowi także talentów wojskowych, które dostrzegano również z bizantyńskiej perspektywy. Również pisarstwo historyczne w Bułgarii było łaskawe i przychylne dla Symeona, podkreślając jego walory, jak wykazał Autor. W krótkim „Zakończeniu” Mirosław J. Leszka udanie podsumowuje bohatera swej książki, jego program polityczny tak w odniesieniu do Bizancjum, jak i Bułgarii.

Recenzent musi ponarzekać, ale powodów do narzekań nie ma zbyt wiele. Transliteracja arabskich terminów nie wygląda budująco, jednak wiadomo, o co chodzi. Zatem z obowiązku wspomnę o dostrzeżonych usterkach. W przypisie 33 na stronie 201 Autor, zdaje się z drugiej ręki, korzystał z przekazu Al-Mas 'ūdiego pisząc o wyprawie morskiej niejakiego „Tamala al-Dulaf”. Ale odwołując się oryginału dzieła „Murūğ ad-dahab wa-ma‘ādin al-ğauhar” (Złote łaki i kopalnie drogich kamieni) Al-Mas'ūdiego czytamy, że pisał on o tej wyprawie datując ją na 312 rok hidżry, czyli od 14 IV 924 do 2 IV 925 roku (Maçoudi, Les prairies d'or, texte et traduction par C. Barbier de Meynard et Pavet de Courteille, t. II, Paris 1863, s. 16-17), a nie „924? (923?) r.” (przyp. 33, s. 201). Jak donosi Al-Mas‘ūdi, Tamal był eunuchem, a jego przydomek brzmiał natomiast az-ulfî. Wzmiankowany „kalif” (s. 200), czyli Abū Muhammad 'Abd Allāh ibn al-Ḥusayn al-Mahdī był jedynie samozwańcem fatymidzkim, którego Bagdad nigdy nie uznał, podobnie jak innych tego typu „kalifów”. Wedle prawa muzułmańskiego kalif mógł być tylko jeden.

Książka od strony wydawniczej prezentuje się równie okazale, jak jej treść. Trafność uwag, logika, wyważone sądy, dobry język, znakomita znajomość źródeł i obcej literatury przyniosły znakomite efekty. Można tylko gratulować Autorowi, ale i polskiemu czytelnikowi, że mamy okazję zapoznać się z tym dziełem, którego treści może nam zazdrościć nie tylko bułgarski historyk.

\title{
Zdzisław Pentek
}

Milijan a Kajmakamova, Vlast $i$ istorija $v$ Srednovekovna Bălgarija VII-XIV vek, Paradigma, Sofija 2011, ss. 340.

Milijana Kajmakamowa od wielu już lat zajmuje się średniowieczną historiografią bułgarską. Owocem jej badań w tym zakresie jest opublikowanie kilkudziesięciu artykułów oraz dwóch prac monograficznych (w tym recenzowanej) ${ }^{1}$. Władza i histo-

\footnotetext{
${ }^{1}$ Pełną bibliografię prac Autorki do roku 2011 znajdzie czytelnik w: Bălgarsko srednovekovie: obščestvo, vlast, istorija, red. G.N. Nikolov, Sofija 2013, s. 17-25.
} 
ria w średniowiecznej Butgarii stanowi z jednej strony swoiste podsumowanie dotychczasowych poszukiwań naukowych jej autorki, z drugiej zaś wytyczenie ich nowych kierunków.

Książka podzielona została na cztery podstawowe części. W pierwszej z nich (Propagandata na vlastta v bălgarskoto chanstvo i načaloto na bălgarskata istoriopis (VIII-sredata na IX v.), s. 43-114) Autorka przedstawia początki bułgarskiej historiografii (okres pogański po połowę IX w.) i obecność w niej kwestii związanych z władzą państwową. Z tego okresu do naszych czasów zachował się tzw. Imiennik bułgarskich chanów i szereg inskrypcji o różnym charakterze (np. upamiętniające zwycięstwa, traktaty pokojowe). W pierwszym fragmencie tej części pracy badaczka dokonuje wszechstronnej analizy Imiennika, opowiadając się za teorią, że powstał on w latach siedemdziesiątych VIII w., a jego tekst został zapewne wykuty na madarskiej skale, jak również w jakiś sposób upubliczniony w Plisce. Jego gatunek historiograficzny definiuje jako chańskq kronikę. Uznaje go za cenne źródło dla poznania początków państwowości bułgarskiej i solidną podstawę dla rozwoju średniowiecznej historiografii bułgarskiej. Jego szczególna waga, według M. Kajmakamowej, polega na wskazaniu na starożytne pochodzenie bułgarskiej tradycji państwowej i określeniu roli władcy jako uosobienia państwa i narodu (s. 101). W drugiej partii rozdziału I Autorka analizuje inskrypcje, wskazując na ich znaczenie propagandowe. To, co szczególnie jest $\mathrm{w}$ nich widoczne to idea wierności i szacunku wobec władcy, co z pewnością służyć miało budowaniu jego silnej pozycji w państwie. Badaczka podkreśla, że używanie języka greckiego w inskrypcjach, umieszczanie ich w ważnych punktach komunikacyjnych, przyczyniało się do tego, że oddziaływały one także na cudzoziemców przybywających do Bułgarii.

W części drugiej (Svetovnata istorija v propagandnata politika na car Simeon (893-927) i razvitieto na bălgarskata chronografia, s. 115-156) M. Kajmakamowa zajmuje się bułgarską historiografią w dobie rządów Symeona I Wielkiego. Wskazuje, na wyjątkową jej popularność. Wtedy to powstały tłumaczenia na język słowiański m.in. Kroniki wielkanocnej, Chronografii Jana Malalasa czy Eklogé chronografias Jerzego Synkellosa, jak również dzieła oryginalne takie jak: Historyki Konstantyna Presławskiego i tzw. Bułgarski chronograf. Jak się powszechnie sądzi rolę inspiratora, przy powstawaniu zarówno thumaczeń, jak i prac oryginalnych, odegrał sam Symeon, człowiek znakomicie znający kulturę bizantyńską. Władca, jak przekonywająco argumentuje M. Kajmakamowa, chciał wykorzystać literaturę do ideologicznego uzasadnienia swojej pozycji, tak wewnątrz Bułgarii, jak i w chrześcijańskiej ekumenie. Temu ostatniemu celowi służyło wpisanie losów Bułgarii w dzieje powszechne i określenie jej miejsca w Boskim planie. Było to szczególnie istotne w sytuacji, kiedy państwo bułgarskie rywalizowało z cesarstwem bizantyńskim.

Część trzecia (Istoričesko săznanie $i$ istoričeska pamet na bălgarite $v$ epochata na vizantijskata vlast v bălgarskite zemi (XI-XII v.), s. 157-216) poświęcona została literaturze historycznej $\mathrm{w}$ okresie, kiedy ziemie bułgarskie znajdowały się pod panowaniem bizantyńskim. Charakterystycznym dla tego etapu nurtem historiograficznym była tzw. literatura historyczno-apokaliptyczna. Badaczka analizuje 
jej najbardziej znaczące dzieła. Szczególną uwagę poświęca tzw. Bułgarskiej kronice apokryficznej ${ }^{2}$. Literatura historyczno-apokaliptyczna, powstała w kręgu duchowieństwa bułgarskiego, była z jednej strony próbą zachowania pamięci o dziejach suwerennego państwa bułgarskiego, $\mathrm{z}$ drugiej zaś znalezienia płaszczyzny porozumienia z Bizantyńczykami i pogodzenia się z zaistniałą sytuacją. Te dwa cele realizowane były przy pomocy wątków religijnych. Bułgarzy i Grecy (Bizantyńczycy) wspólnie wpisani zostali w Boski plan dziejów, jako kontynuatorzy tradycji Rzymu. M. Kajmakamowa słusznie upatruje znaczenia tego typu literatury historycznej nie tylko (czy raczej nie tyle) w przekazywaniu informacji o bułgarskiej przeszłości, co w zachowaniu tradycji państwowej przez blisko sto siedemdziesiąt lat bizantyńskiej niewoli. Stała się ona swoistym pomostem między Pierwszy i Drugim Carstwem Bułgarskim.

W części czwartej (Vlast i istorija v Bălgarija (kraja na XII-XIV v.), s. 217-300 Autorka analizuje wykorzystanie literatury historycznej przez władców w dobie II Carstwa Bułgarskiego. W ciągu pierwszych dekad jego istnienia główny nacisk położony został na wskazanie związków między odrodzonym państwem bułgarskim a Pierwszym Carstwem, jak również kwestię uzasadnienia praw do dziedziczenia tronu w obrębie rodu Asenidów. W tym czasie argumenty historyczne były ważkim narzędziem w bułgarskiej dyplomacji (np. korespondencja Kalojana z papieżem Innocentym III).

Głównym wątkiem rozważań M. Kajmakamowej w rozdziale czwartym jest obecność w bułgarskiej literaturze historycznej idei Bułgarii jako następcy Bizancjum (Tyrnowo jako Trzeci Rzym). Autorka wnikliwie analizuje pojawienie się tej idei (tu szczególnie dużo uwagi poświęca tekstowi funkcjonującemu pod tytułem Pandechovo proročesko skazanie), jak również jej uzasadnienie (w dobie IV krucjaty Bułgaria staje się obrońcą prawosławnego świata przed łacinnikami, zajmując miejsce Bizancjum). Wskazuje również na te okoliczności, które wpływały na jej popularność w różnych momentach dziejów Drugiego Carstwa (np. za panowania Jana Aleksandra).

Pracę uzupełniają wstęp (s. 9-14), wprowadzenie 15-42, zakończenie (s. 301-310), spis źródeł (311-316) i literatury (s. 317-338) oraz skróty (s. 339-340)

Rozważania M. Kajmakamowej oparte na wszechstronnej i wnikliwej analizie źródeł i przy wykorzystaniu bogatej, wielojęzycznej literatury przedmiotu wyraźnie wskazują jak istotną rolę odgrywała historia w polityce władców bułgarskich, a szczególnie Symeona Wielkiego (893-927), Kałojana (1197-1207) i Jana Aleksandra (1131-1355). Stanowiła ona narzędzie tak w propagowaniu idei lansowanych przez władców, jak i w kształtowaniu pożądanych przez nich postaw społeczeństwa.

\footnotetext{
${ }^{2}$ Właściwy tytuł tego dzieła w języku polskim należałoby oddać jako: Opowieść proroka Izajasza o tym jak zostat przez anioła wyniesiony do siódmego nieba - wyd. I. Biljarski, Skazanije na Isaja proroka i formirovaneto na političeskata ideologia na rannosrednovekovna Bălgarija, Sofija 2011, s. 15-23 (thum polskie M. Skowronek - Butgarska kronika apokryficzna. Stowo proroka Izajasza o tym jak zostat przez anioła wyniesiony do siódmego nieba, [in:] Apokryfy i legendy starotestamentowe Stowian Poludniowych, wyb., red. G. Minczew, M. Skowronek, Kraków 2006, s. 62-69).
} 
Książka Milijany Kajmakamowej to dzieło ważne i inspirujące. Wszechstronnie ukazuje średniowieczną historiografię bułgarską na różnych etapach rozwoju w kontekście jej związków z życiem politycznym. Z pewnością wejdzie do bułgarskiego, jak międzynarodowego obiegu naukowego.

Mirostaw J. Leszka

Zdenko Zlatar, Dubrovnik's Merchants and Capital in the Ottoman Empire (1520-1620). A Quantitative Study, The Isis Press, Istanbul 2010, ss. 664.

Zdenko Zlatar jest znanym i cenionym badaczem dziejów Europy ŚrodkowoWschodniej. Urodzony w Dubrowniku, odbył studia i doktoryzował się na Uniwersytetach w Chicago (DePaul Univerisity, Univerisity of Illinois). Od 1990 r. był członkiem a od 2005 r. wiceprezesem Commission internationale des études historiques slaves w Paryżu, czołowej organizacji zrzeszającej badaczy zajmujących się dziejami Słowian. Z. Zlatar wchodzi także w skład zarządu International Association for the Social and Economic History of the Ottoman Empire oraz w komitetu redakcyjnego East European Quaterly - czołowego czasopisma zajmującego się historią Europy Wschodniej. Obecnie pracuje jako wykładowca na Wydziale Historycznym Uniwersytetu w Bostonie w Australii.

W bardzo szerokim spektrum zainteresowań Z. Zlatara (m.in. prowadzi obecnie badania nad rodzinami przemysłowców i finansistów rosyjskich przełomu XIX i XX w.) szczególne miejsce zajmowały zawsze dzieje jego rodzinnego Dubrownika. Poza licznymi artykułami w czasopismach, w wydawanej przez Uniwersytet Columbia serii East European Monographs ukazały się w 1992 r. dwie jego książki: Between the Double Eagle and the Crescent: The Republic of Dubrovnik and the Origins of the Eastern Question oraz Our Kingdom Come: The Counter-Reformation, the Republic of Dubrovnik, and the Liberation of the Balkan Slavs ${ }^{3}$.

Wydana w tureckim wydawnictwie „Isis” ostatnia książka Z. Zlatara Dubrovnik's Merchants and Capital in the Ottoman Empire (1520-1620). A Quantitative Study, jest owocem jego wieloletnich studiów nad kapitałem kupieckim w Turcji i Dubrowniku w czasach wczesnonowożytnych ${ }^{4}$. Trzeba zaznaczyć, że już wcześniej badacze z kra-

${ }^{3}$ Z. Zlatar, Between the Double Eagle and the Crescent: The Republic of Dubrovnik and the Origins of the Eastern Question, East European Monographs, Columbia University Press, New York 1992; idem, Our Kingdom Come: The Counter-Reformation, the Republic of Dubrovnik, and the Liberation of the Balkan Slavs, East European Monographs, Columbia University Press, New York 1992.

${ }^{4}$ Częściowe wnioski przedstawił autor już w 2007 w swym artykule wydanym w języku chorwackim w dubrownickich Anali. Patrz: Z. Zlatar, Udio vlastele u dubrovačkoj kreditnoj trgovini (1520-1623). Kvantitativna analiza vjerovnika, „Anali” vol. 45, Dubrovnik 2007, s. 131-158. 